Portland State University

PDXScholar

\title{
Winter Climate Change Affects Growing-Season Soil Microbial Biomass and Activity in Northern Hardwood Forests
}

Jorge Durán

Cary Institute of Ecosystem Studies

Jennifer L. Morse

Portland State University, jlmorse@pdx.edu

Peter M. Groffman

Cary Institute of Ecosystem Studies

John L. Campbell

USDA Forest Service

Lynn M. Christenson

Vassar College

Follow this and additional works at: https://pdxscholar.library.pdx.edu/esm_fac

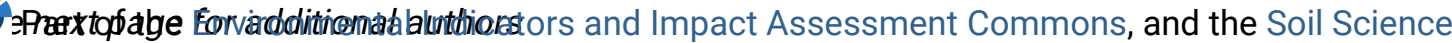
Commons

Let us know how access to this document benefits you.

\section{Citation Details}

Durán, J., Morse, J., Groffman, P., Campbell, J., Christenson, L., Driscoll, C., \& ... Templer, P. (2014). Winter climate change affects growing-season soil microbial biomass and activity in northern hardwood forests. Global Change Biology.

This Article is brought to you for free and open access. It has been accepted for inclusion in Environmental Science and Management Faculty Publications and Presentations by an authorized administrator of PDXScholar. Please contact us if we can make this document more accessible: pdxscholar@pdx.edu. 


\section{Authors}

Jorge Durán, Jennifer L. Morse, Peter M. Groffman, John L. Campbell, Lynn M. Christenson, Charles T. Driscoll, Timothy J. Fahey, Melany C. Fisk, Mryon J. Mitchell, and Pamela H. Templer 


\title{
Winter climate change affects growing-season soil microbial biomass and activity in northern hardwood forests
}

\author{
JORGE DURÁN ${ }^{1,2}$, JENNIFER L. MORSE ${ }^{3}$, PETER M. GROFFMAN ${ }^{1}$, JOHN L. CAMPBELL ${ }^{4}$, \\ LYNN M. CHRISTENSON ${ }^{5}$, CHARLES T. DRISCOLL $^{6}$, TIMOTHY J. FAHEY ${ }^{7}$, MELANY C. \\ FISK $^{8}$, MYRON J. MITCHELL ${ }^{9}$ and PAMELA H. TEMPLER ${ }^{10}$ \\ ${ }^{1}$ Cary Institute of Ecosystem Studies, Box AB, 2801 Sharon Turnpike, Millbrook, NY 12545, USA, ${ }^{2}$ Centre for Functional Ecology, \\ Department of Life Sciences, University of Coimbra, 3001-401 Coimbra, Portugal, ${ }^{3}$ Environmental Science and Management, \\ School of the Environment, Portland State University, PO Box 751 (ESM), Portland, OR 97207, USA, ${ }^{4}$ Northern Research \\ Station, USDA Forest Service, 271 Mast Road, Durham, NH 03824, USA, ${ }^{5}$ Biology Department, Vassar College, 124 Raymond \\ Ave., Poughkeepsie, NY 12604, USA, ${ }^{6}$ Department of Civil and Environmental Engineering, Syracuse University, 900 S Crouse \\ Ave., Syracuse, NY 13210, USA, ${ }^{7}$ Department of Natural Resources, Cornell University, Ithaca, NY 14850, USA, ${ }^{8}$ Department of \\ Zoology, Miami University, 501 E High St., Oxford, OH 45056, USA, ${ }^{9}$ Department of Environmental and Forest Biology, SUNY- \\ College of Environmental Science and Forestry, 1 Forestry Dr, Syracuse, NY 13210, USA, ${ }^{10}$ Department of Biology, Boston \\ University, 5 Cummington Street, Boston, MA 02215, USA
}

\begin{abstract}
Understanding the responses of terrestrial ecosystems to global change remains a major challenge of ecological research. We exploited a natural elevation gradient in a northern hardwood forest to determine how reductions in snow accumulation, expected with climate change, directly affect dynamics of soil winter frost, and indirectly soil microbial biomass and activity during the growing season. Soils from lower elevation plots, which accumulated less snow and experienced more soil temperature variability during the winter (and likely more freeze/thaw events), had less extractable inorganic nitrogen $(\mathrm{N})$, lower rates of microbial $\mathrm{N}$ production via potential net $\mathrm{N}$ mineralization and nitrification, and higher potential microbial respiration during the growing season. Potential nitrate production rates during the growing season were particularly sensitive to changes in winter snow pack accumulation and winter soil temperature variability, especially in spring. Effects of elevation and winter conditions on $\mathrm{N}$ transformation rates differed from those on potential microbial respiration, suggesting that $\mathrm{N}$-related processes might respond differently to winter climate change in northern hardwood forests than C-related processes.
\end{abstract}

Keywords: carbon, global change, microbial respiration, mineralization, nitrification, nitrogen, soil frost

Received 21 January 2014; revised version received 9 April 2014 and accepted 25 April 2014

\section{Introduction}

Global climate is anticipated to become significantly warmer over the next decades (Intergovernmental Panel on Climate Change, 2013). In northeastern North America air temperatures are projected to increase by $2.1-5.3{ }^{\circ} \mathrm{C}$ by 2100 , depending on the model used and its formulations (Hayhoe et al., 2008). Many studies in diverse ecosystems throughout the world have demonstrated that changing climate can substantially alter $\mathrm{C}$ and N cycles and budgets (Beier et al., 2008; Pendall et al., 2008; Luo et al., 2011). Understanding the responses of terrestrial ecosystems to global change remains a major challenge of current ecological

Correspondence: Present address: Jorge Durán, Centre for Functional Ecology, Department of Life Sciences, University of Coimbra, 3001-401 Coimbra, Portugal, tel. +1 8456777600,

fax +1 8456775976, e-mail: humia20@gmail.com research (Sternberg et al., 2011). Temperate forest biomes contain approximately $10 \%$ of global soil carbon (C) stocks, and most terrestrial C sequestration at midlatitudes in the Northern Hemisphere occurs in seasonal montane forest ecosystems (Monson et al., 2006; Rasmussen et al., 2006). There is, therefore, a need to assess how climate change will influence ecosystem processes in these systems to improve projections of ecological responses to different climate change scenarios (Tilman \& Downing, 1994; Durán et al., 2013).

Most climate change studies have focused on effects during the growing season. However, in many northern temperate and boreal ecosystems, changes in temperature and precipitation have been and will continue to be more pronounced during winter than during summer (Hayhoe et al., 2007; Intergovernmental Panel on Climate Change, 2013). This understanding has increased interest in winter climate change and its 
effects (Campbell et al., 2005; Groffman et al., 2011; Durán et al., 2013). Warmer winter temperatures can reduce the depth and duration of snow pack and increase soil freezing which, in turn, can affect microbial, soil, plant, and other ecosystem processes (Brooks et al., 2011; Blankinship \& Hart, 2012), not only during the winter, but also for the following growing season (Durán et al., 2013). However, the complex nature of snow pack/soil freezing, the dynamics of soils, and the varied responses of ecosystem processes and organisms to climatic changes and stresses have challenged our ability to project how winter climate change will influence nutrient cycles (Walther et al., 2002; Henry, 2008).

Insight into the effects of winter climate change on forest ecosystem processes has been gained by using multiple experimental approaches. Our study exploited a natural elevation gradient in a northern hardwood forest at the Hubbard Brook Experimental Forest (HBEF) in New Hampshire, United States, which encompasses relatively uniform soil and forest vegetation and produces a difference in mean annual temperature $\left(\sim 2{ }^{\circ} \mathrm{C}\right)$ that is very similar to what is projected to occur with global warming over the next 50-100 years at the HBEF (Hayhoe et al., 2007). This gradient enabled us to evaluate, under natural conditions, how variable amounts of snow accumulation directly affect soil winter frost dynamics and indirectly affect soil microbial biomass and activity during the growing season in northern hardwood forests. Climate change has been marked at the HBEF, with annual average annual air temperature increasing by $0.17-0.29^{\circ} \mathrm{C}$ per decade over the past 50 years. Warming has been more noticeable in winter than in summer (Campbell et al., 2007; Hamburg et al., 2013) which has led to significant reductions in maximum annual snow pack depth and the number of days with snow cover (Campbell et al., 2010). Our study builds on previous analyses of relationships between snow depth, soil freezing, and $\mathrm{N}$ and $\mathrm{C}$ cycling at the HBEF based on experimental snow pack manipulations. These studies have found microbial biomass and activity to be surprisingly unresponsive to winter climate change (Groffman et al., 2001, 2010), with the observed changes in forest ecosystem $\mathrm{N}$ and $\mathrm{C}$ cycling apparently driven by overwinter root damage associated with soil freezing (Fitzhugh et al., 2001; Tierney et al., 2001; Cleavitt et al., 2008; Comerford et al., 2013; Campbell et al., 2014). Our current study explored relationships among snow, frost, and microbial biomass and activity in more detail, using a more natural experimental design (natural climate gradient rather than snow manipulation), more intensive temporal and spatial sampling, and new analytical approaches. We hypothesized that a shallower snow pack would be associated with greater soil freezing, and that these changes would affect $\mathrm{C}$ and $\mathrm{N}$ processing during the following growing season. Since soil microbial populations and roots affected by soil freezing are likely to recover after this disturbance during the growing season, we also hypothesized that the influence of winter climate change would be most apparent at the beginning of the growing season and diminish later in the growing season.

\section{Materials and methods}

This study was conducted at the HBEF $\left[43^{\circ} 56^{\prime} \mathrm{N}, 71^{\circ} 45^{\prime} \mathrm{W}\right.$; New Hampshire (United States)]. The climate is cool, humid, and continental with average monthly air temperatures ranging from -9 to $18{ }^{\circ} \mathrm{C}$. Average annual precipitation is $1400 \mathrm{~mm}$. The snow pack usually persists from late December until midApril, with maximum depths in March. Soils are largely Spodosols developed from unsorted basal tills $(75-100 \mathrm{~cm}$ deep, $\mathrm{pH} 4$.0; Soil Survey Staff, 2006) with a $6.5 \mathrm{~cm}$ thick organic surface layer, overlying mineral soil (Bohlen et al., 2001).

In October 2010, we selected 20 independent (separated by $>300 \mathrm{~m}) 10 \mathrm{~m}$ diameter plots along an elevation gradient that spanned 375-775 $\mathrm{m}$ asl. This gradient encompasses a range in mean annual air temperature of $\sim 2.5^{\circ} \mathrm{C}$ that is similar to the change projected to occur with climate change over the next 50-100 years in northeastern North America (Hayhoe et al., 2007). There was relatively little variation in soil types with all plots being located on well to moderately well-drained soils dominated by Typic Haplorthods). The vegetation in the plots was characteristic of northern hardwood forests and was dominated by sugar maple (Acer saccharum) along the gradient (Schwarz et al., 2003). In each plot, we continuously measured soil temperature and volumetric water content (WC) at $5 \mathrm{~cm}$ depth with Decagon $5 \mathrm{TM}^{\circledR}$ combination probes coupled to Decagon $\mathrm{EM} 50^{\circledR}$ dataloggers. When examining relationships between soil moisture and temperature with microbial variables, we used average values for the 30 days prior to the soil sampling dates. At three sampling points per plot we used a Federal snow sampling tube (Rickly Hydrological Company, Columbus, $\mathrm{OH}$, United States) to measure snow depth and snow water content (water equivalent) biweekly, and installed one frost tube per plot to measure soil frost depth biweekly throughout the winters of 2010/2011 and 2011/2012 (Hardy et al., 2001). We integrated continuous measurements of snow depth, soil frost depth, and snow water content by plotting those variables ( $y$ axis) vs. time ( $x$ axis) and then using a trapezoidal approach to calculate the area beneath the curves. Integration of time series observations is a useful approach to examine the cumulative effects of environmental drivers on ecosystem processes or phenomena (Fekedulegn et al., 2007; Morse et al., 2012). This calculation produced seasonally integrated, unitless indices of winter climate conditions, hereafter referred as to 'snow', 'frost', and 'snow water'. As a measure of winter soil temperature variability, and as an indicator of the likely occurrence of freeze/thaw events, we calculated the SDL coefficient of variation [standard deviation of log-transformed observations; (McArdle \& Gaston, 1995)] of daily soil winter temperatures (hereafter referred as to 'wstv'). 
Ten cylindrical $(5 \mathrm{~cm}$ diameter) soil samples were taken from each plot in May in 2011 and 2012 ('Spring 2011' and 'Spring 2012', respectively), and in August of 2011 and 2012 ('Summer 2011' and 'Summer 2012', respectively). Only the OiOe horizon was collected. Samples were hand-sorted to remove roots and rocks, homogenized, and held at field moisture for all analyses. All soil samples were stored at $4{ }^{\circ} \mathrm{C}$ after sampling until analysis (less than 1 week). Gravimetric water content was determined by drying at $60{ }^{\circ} \mathrm{C}$ for $48 \mathrm{~h}$ (McInnes $\&$ Weaver, 1994). Soil organic matter content (OM) was determined by loss on ignition at $450{ }^{\circ} \mathrm{C}$ for $4 \mathrm{~h}$ (Nelson \& Summers, 1996). We measured soil total inorganic $N$ content (TIN), potential microbial respiration (PMR), $\mathrm{N}$ mineralization (PM), and nitrification (PN) rates, and soil microbial biomass $\mathrm{N}$ (as a proxy of microbial biomass; $\mathrm{MB}$ ) using the chloroform fumigation-incubation method (Jenkinson \& Powlson, 1976) as described by (Durán et al., 2013). Soils were fumigated to lyse microbial cells and then inoculated with fresh soil. The soils were then incubated for 10 days and the $\mathrm{NH}_{4}{ }^{+}$released during this incubation is assumed to be directly proportional to the amount of $\mathrm{N}$ in the microbial biomass of the original sample. $\mathrm{NH}_{4}{ }^{+}$was quantified colorimetrically after $\mathrm{KCl}$ extraction using a flow injection analyzer (Lachat Quikchem 8100). No proportionality constant was used to calculate biomass $\mathrm{N}$ from the $\mathrm{NH}_{4}{ }^{+}$produced during the incubation. Inorganic $\mathrm{N}$ and $\mathrm{CO}_{2}$ production were also measured in parallel incubations of unfumigated soil to provide estimates of microbial respiration, potential net $\mathrm{N}$ mineralization rates, potential net nitrification rates, and pools of readily available (labile) $\mathrm{N}$ and $\mathrm{C}$. Microbial respiration was quantified from the amount of $\mathrm{CO}_{2}$ evolved over the 10-day incubation for non-fumigated samples. Potential $\mathrm{N}$ mineralization (PM) was calculated as the accumulation of total inorganic $\mathrm{N}\left(\mathrm{NO}_{3}{ }^{-}+\mathrm{NH}_{4}{ }^{+}\right.$; TIN) over the period of the incubation. Potential net nitrification (PN) was calculated as the accumulation of $\mathrm{NO}_{3}{ }^{-}$over the course of the incubation. Inorganic $\mathrm{N}$ was quantified by extracting soil samples with $2 \mathrm{M} \mathrm{KCl}$ and analyzing them colorimetrically as described above.

Relationships between individual variables were explored with Pearson product moment correlations and univariate linear regression (OLS) analyses. To evaluate the effect of the variation in winter climate on spring (May) and summer (August) PM, PN, and PMR rates, we used a multimodel inference approach based on information theory and OLS regression to evaluate the relative importance of these variables in different seasons (Burnham \& Anderson, 2002). To reduce the complexity of the analysis, we extracted the only meaningful component (i.e. with eigenvalue $>1$ ) from a principal-components analysis of three highly correlated variables: 'snow', 'snow water', and 'swtv'. This new variable ('winter') was used as an integrative indicator of winter conditions. We conducted three different analyses for each sampling ('Spring 2011', 'Spring 2012', 'Summer 2011', and 'Summer 2012') using PM, PN and PMR as response variables, and 'winter' along with other potential predictor variables as independent factors.

To better understand the effect of winter conditions on growing-season soil transformation rates, we used structural equation modeling (SEM; Grace, 2006) to evaluate the relationships between our three dependent variables (PM, PN or PMR), and the expected predictors in each season elevation was also included to account for possible spatial autocorrelation in our data, and to reduce the complexity of the analysis and gain explanatory power, data from 'Spring 2011' and 'Spring 2012' were jointly analyzed, as well as data from 'Summer 2011', and 'Summer 2012' (Delgado-Baquerizo et al., 2013). Data were tested for normality using the Shapiro-Wilk statistic and transformed when necessary. Statistical analyses were carried out using SPSS 20.0, AMOS 19.0, and SAM 4.0 statistical packages.

\section{Results}

There was a marked difference in the winter conditions during the 2 years of our study (Fig. 1). The first winter had more snow and snow water $(P<0.001)$, but less soil winter temperature variability $(P=0.09)$ than the second winter. No significant differences between winters were evident for soil frost. The PCA-derived 'winter' variable was always negatively related to 'snow', and 'snow water' and positively related to the 'swtv' index, and encompassed $\sim 80 \%$ and $\sim 78 \%$ of the explained variance of those three variables in the first and second winter of the study respectively (see Materials and methods section). There was a statistically significant positive relationship between elevation and all winter climate-related variables, except for soil 'frost' (Table 1; Fig. 2). High elevation plots experienced significantly higher values of 'snow' and 'snow water' than low elevation plots, whereas the variability of soil winter temperature ('swtv') decreased significantly with increasing elevation. Soil temperature significantly

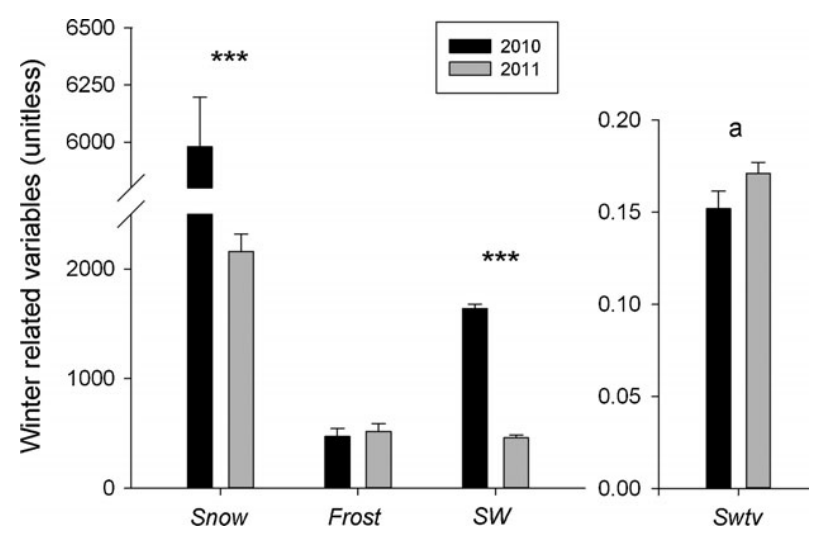

Fig. 1 Average 'snow', 'frost', 'snow water' (SW), and variability of winter soil temperatures ('Swtv') for the 2010-2011 (black bars) and 2011-2012 (gray bars) winters. Values are mean with standard error. ${ }^{* *} P<0.001,{ }^{* *} P<0.01,{ }^{*} P<0.05$, ${ }^{a} P<0.1$ (distance-based permutational repeated measures ANOVA) refer to significant differences between years. 
Table 1 Univariate linear regressions [ordinary least-squares (OLS)] between elevation (as the only predictor) and 'snow', 'snow water', 'soil frost', the variability of soil winter temperature ('wtsdl'), winter conditions ('winter'; see Materials and methods section), soil temperature (Soil temp), volumetric water content $(\mathrm{WC})$, soil organic matter $(\mathrm{OM})$, microbial biomass (MB), total inorganic $N$ (TIN), potential mineralization rates $(\mathrm{PM})$, potential nitrification rates $(\mathrm{PN})$ and microbial respiration (PMR), in Spring and Summer (only in winter for 'snow', 'snow water', 'frost', 'frzthaw and 'winter') of 2011 and 2012

\begin{tabular}{|c|c|c|c|c|c|}
\hline & & \multicolumn{4}{|c|}{ Elevation } \\
\hline & & \multicolumn{2}{|l|}{2011} & \multicolumn{2}{|l|}{2012} \\
\hline & & Spring & Summer & Spring & Summer \\
\hline \multirow[t]{2}{*}{ 'Snow' } & $R$ & \multicolumn{2}{|c|}{0.82} & \multicolumn{2}{|c|}{0.83} \\
\hline & $P$ & \multicolumn{2}{|c|}{$<0.001$} & \multicolumn{2}{|c|}{$<0.001$} \\
\hline \multirow[t]{2}{*}{ 'Snow water' } & $R$ & \multicolumn{2}{|c|}{0.68} & \multicolumn{2}{|c|}{0.77} \\
\hline & $P$ & \multicolumn{2}{|c|}{$<0.005$} & \multicolumn{2}{|c|}{$<0.001$} \\
\hline \multirow[t]{2}{*}{ 'Soil frost' } & $R$ & \multicolumn{2}{|c|}{0.19} & \multicolumn{2}{|c|}{0.31} \\
\hline & $P$ & \multicolumn{2}{|c|}{0.43} & \multicolumn{2}{|c|}{0.18} \\
\hline \multirow[t]{2}{*}{ ‘Wtsdl' } & $R$ & \multicolumn{2}{|c|}{-0.73} & \multicolumn{2}{|c|}{-0.64} \\
\hline & $P$ & \multicolumn{2}{|c|}{$<0.001$} & \multicolumn{2}{|c|}{$<0.005$} \\
\hline \multirow[t]{2}{*}{ 'Winter' } & $R$ & \multicolumn{2}{|c|}{-0.84} & \multicolumn{2}{|c|}{-0.82} \\
\hline & $P$ & \multicolumn{2}{|c|}{$<0.001$} & \multicolumn{2}{|c|}{$<0.001$} \\
\hline \multirow[t]{2}{*}{ Soil temp } & $R$ & -0.64 & -0.87 & -0.21 & -0.91 \\
\hline & $P$ & $<0.005$ & $<0.001$ & 0.37 & $<0.001$ \\
\hline \multirow[t]{2}{*}{ WC } & $R$ & 0.28 & 0.39 & 0.11 & 0.26 \\
\hline & $P$ & 0.239 & 0.084 & 0.633 & 0.27 \\
\hline \multirow[t]{2}{*}{$\mathrm{OM}$} & $R$ & 0.027 & 0.02 & 0.027 & 0.02 \\
\hline & $P$ & 0.91 & 0.94 & 0.91 & 0.94 \\
\hline MB & $R$ & -0.2 & 0.03 & -0.15 & -0.17 \\
\hline & $P$ & 0.39 & 0.91 & 0.54 & 0.47 \\
\hline TIN & $R$ & 0.16 & 0.43 & 0.39 & 0.7 \\
\hline & $P$ & 0.497 & 0.059 & 0.088 & $<0.005$ \\
\hline PM & $R$ & 0.35 & 0.28 & 0.48 & 0.43 \\
\hline & $P$ & 0.133 & 0.241 & $<0.05$ & 0.06 \\
\hline PN & $R$ & 0.71 & 0.563 & 0.66 & 0.56 \\
\hline & $P$ & $<0.001$ & $<0.05$ & $<0.005$ & $<0.01$ \\
\hline PMR & $R$ & 0.4 & 0.03 & 0.09 & 0.155 \\
\hline & $P$ & 0.08 & 0.91 & 0.715 & 0.514 \\
\hline $\mathrm{df}=19$ & & & & & \\
\hline
\end{tabular}

decreased with increasing elevation in Spring 2011, Summer 2011, and Summer 2012 (Table 1; Figures S1 and S2). No statistically significant relationships were found between elevation and OM or WC. Soil TIN in Summer 2012, PM in Spring 2012, and PN in all samplings, increased significantly with elevation (Table 1; Figures S1 and S2).

Univariate linear regression relationships between PM, PN, PMR, and the explored potential drivers varied temporally (Table S1). Winter conditions ('winter') alone significantly explained PN in all samplings (marginally significant in Summer 2012 with $P=0.07$; Table
S1). TIN was significantly related to PM and PN in all samplings (and with PMR in Spring 2011), and MB was significantly related to PM and PMR during all samplings (except for Summer 2012 in PMR). Soil temperature, $\mathrm{WC}$, or $\mathrm{OM}$ were not significant direct drivers of PM, PN, or PMR rates.

The multimodel inference approach showed that the relative importance of winter conditions (i.e. 'winter') was high explaining PN rates in all samplings, and PM rates in Spring 2012 (Fig. 3). The relative importance of winter conditions explaining PNM and PN rates was stronger in spring than in summer in both years. There was no clear influence (nor seasonal or temporal pattern) of winter conditions in explaining PMR. TIN had a strong influence on PM (except for Spring 2012) and PMR rates, and MB had a strong influence on PMR rates, particularly in the spring samplings.

SEM analyses that combined data from the two spring and two summer samplings show that soil temperature and elevation consistently had significant positive relationships with $\mathrm{N}$ transformation rates (except for PN in spring, when the influence of elevation was not significant; Fig. 4a-d). PN was also significantly and negatively affected by winter conditions in spring (Fig. 4c). PM was also positively and significantly affected by the size of the microbial biomass in both seasons, whereas the direct influence of the 'winter' on PM was only marginally significant (Fig. 4a and b). Standardized total effects (which include direct and indirect effects) show that PM was mainly positively influenced by microbial biomass, both in spring and summer (Fig. 5a and b respectively). In spring, PN was strongly and negatively influenced by winter conditions, and positively influenced by elevation and temperature (Fig. 5c), whereas in summer it was driven by the positive influence of elevation, temperature, and TIN (Fig. 5d). PMR was mainly driven by the negative effect of soil temperature and the positive effect of the size of the microbial biomass, although winter conditions also exerted some negative influence in spring (Fig. 5e and f).

\section{Discussion}

Winter climate is changing in northeastern North America. At our long-term study site, air temperature has increased by approximately $1{ }^{\circ} \mathrm{C}$ over the last 50 years and this increase has led to significant declines in snow depth, snow water equivalent, and snow cover duration (Campbell et al., 2007). Air temperatures are projected to continue to increase in this region, by $2.1-$ $5.3^{\circ} \mathrm{C}$ by 2100 , depending on the model being used (Hayhoe et al., 2008). Precipitation is also projected to increase in the region, with a greater proportion as rain 

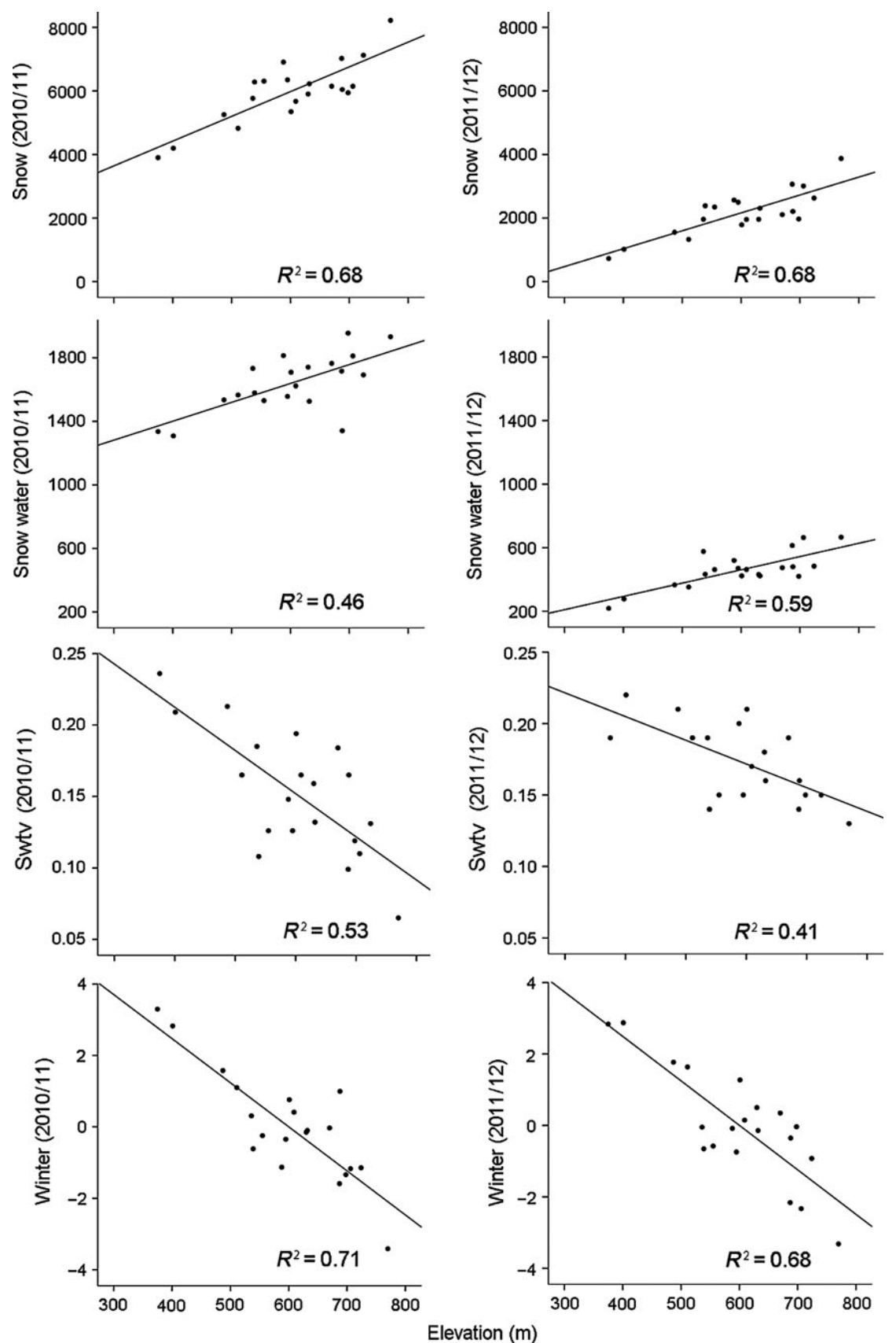

Fig. 2 Significant univariate linear regressions [ordinary least-squares (OLS)] between elevation (as the only predictor) and 'snow', 'snow water', 'frost', 'swtv', and winter conditions ('winter'; see Materials and methods section) in 2011 (left) and 2012 (right). Variable abbreviations are as in Table 1.

rather than as snow, which will further decrease snow pack depth and snow cover duration. While the effects of changes in snow cover on patterns of runoff and streamflow are relatively well-studied in the region (Campbell et al., 2011; Zion et al., 2011), there is uncertainty about the response of soil frost and temperature variability during the next century (Campbell et al., 2010).
Our measurements during two contrasting winters showed that the elevation gradient at the HBEF was effective in providing a wide range of snow- and frostrelated winter conditions. High elevation plots experienced more snow precipitation and snow water during both winters. Whereas the observed negative relationships between snow depth and soil frost across the elevation gradient were not statistically significant, the 

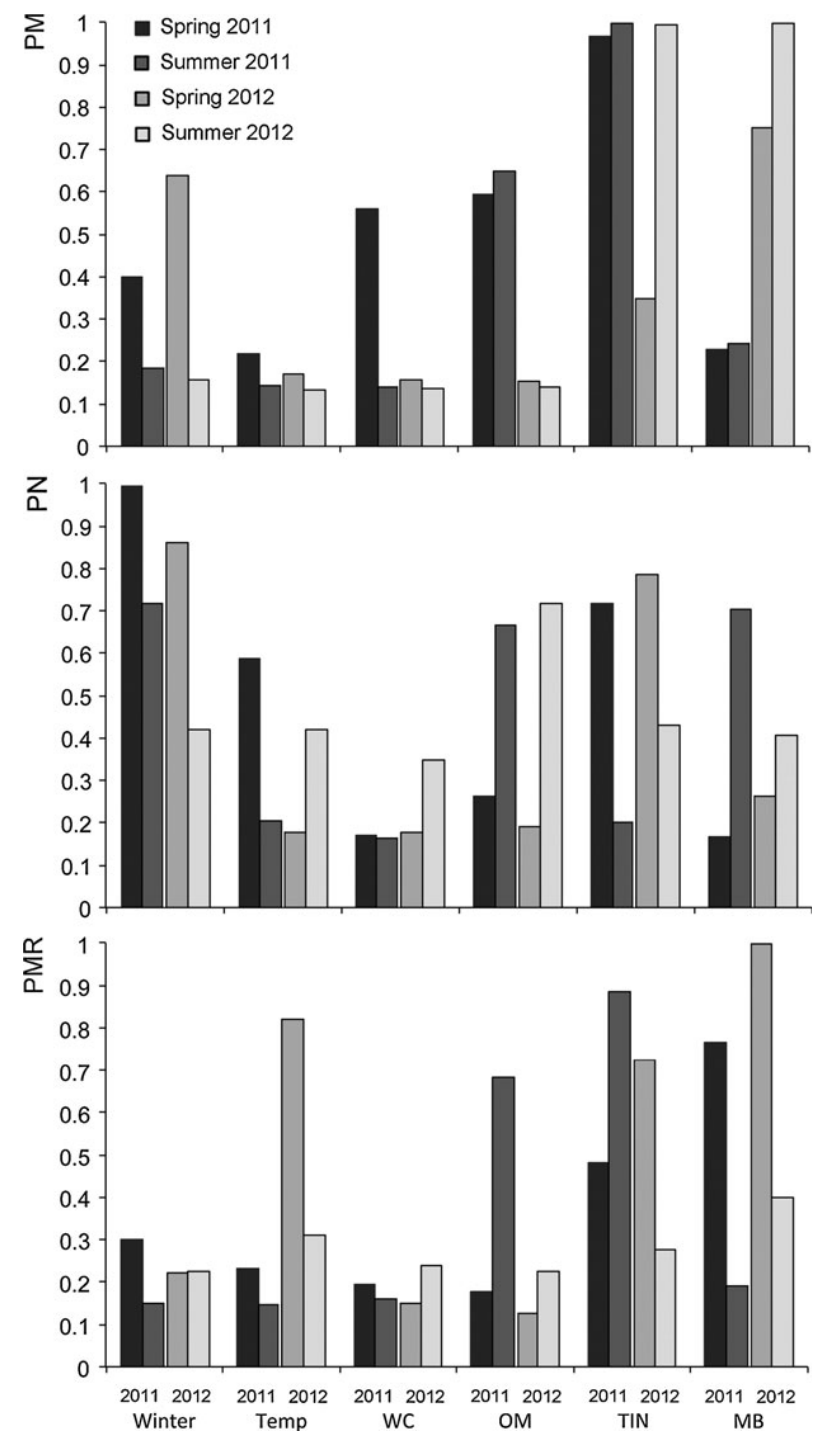

Fig. 3 Relative importance of different predictors explaining potential nitrogen mineralization (PM), nitrification (PN), and microbial respiration (PMR) rates in Spring 2011, Summer 2011, Spring 2012, and Summer 2012. The height of each bar is the sum of the Akaike weights of all models that included the predictor of interest, taking into account the number of models in which each predictor appears. Variable abbreviations are same as in Table 1.

relationships between snow depth and winter soil temperature variation (Figure S3) were significant, which demonstrates that smaller snow accumulation due to climate change is likely to produce a significant increase in the daily soil temperature oscillation in winter. This condition could increase the number of soil freeze/thaw cycles, which are thought to affect a wide range of soil biogeochemical properties via stress or death of microbial biomass, changes in soil structure, fine root mortality, or enhanced mineralization (Schimel \& Clein, 1996; Socci, 2011; Kreyling et al., 2012). Our biweekly soil frost monitoring was not sufficiently frequent to determine whether the increases in soil temperature oscillation increased freeze/thaw events. However, the significant increase in soil temperature fluctuations, that regularly ranged from above to below $0{ }^{\circ} \mathrm{C}$ in the same day in low elevation plots, Figure S4 provide support for the idea that there was a genuine increase in freeze/thaw events in these plots (Henry, 2008).

Soils from low elevation plots consistently had smaller $\mathrm{N}$ concentrations and potential $\mathrm{N}$ mineralization and nitrification rates, during both spring and summer. These results are consistent with the hypothesis that climate warming may lead to decreases in inorganic $\mathrm{N}$ supplies in a warmer world (Groffman et al., 2009; but see Melillo et al., 2011). Furthermore, they may help to explain the remarkable and yet unexplained declines in stream $\mathrm{NO}_{3}{ }^{-}$concentrations and export from northeastern forests that have been observed in recent decades (Goodale et al., 2003; Bernhardt et al., 2005; Bernal et al., 2012; Yanai et al., 2013). Although regression analyses did not reveal consistent significant relationships between $\mathrm{N}$ transformation rates and soil temperature and moisture, they did show a strong and consistent relationship between nitrification rates and winter conditions, mainly in spring (Table S1). Furthermore, 'winter' was of great importance explaining nitrification rates in spring, as shown by the multimodel inference results. Both regression analyses and structural equation modeling showed that the effect of 'winter' on $\mathrm{N}$ nitrification rates and soil inorganic $\mathrm{N}$ in spring was always negative, indicating that lower elevation sites, with smaller depth and duration of snow pack accumulation and higher variability in winter soil temperature were associated with lower nitrate production rates. These results provide strong evidence that winter conditions influenced variation in $\mathrm{N}$ cycling during the subsequent growing season. SEM analyses also revealed that higher soil temperatures in low elevation plots during the growing season consistently had a positive influence on $\mathrm{N}$ transformation rates. However, our data suggest that projected decrease in snow pack accumulation leading to increased winter soil temperature variability (and therefore likely more freeze/thaw events) may overcome this influence and lead to a net decrease in inorganic $\mathrm{N}$ production in northern forests, which, in turn, could exacerbate $\mathrm{N}$ limitation (LeBauer \& Treseder, 2008; Gilliam et al., 2010). In the lower elevation plots, a reduced snow pack and enhanced soil temperature variability may have stressed and/or killed microbial populations, decreasing organic matter decomposition and $\mathrm{N}$ transformation rates, compared with higher elevation plots, where belowground biological processes continued uninterrupted under the snow pack with temperatures continuously above 

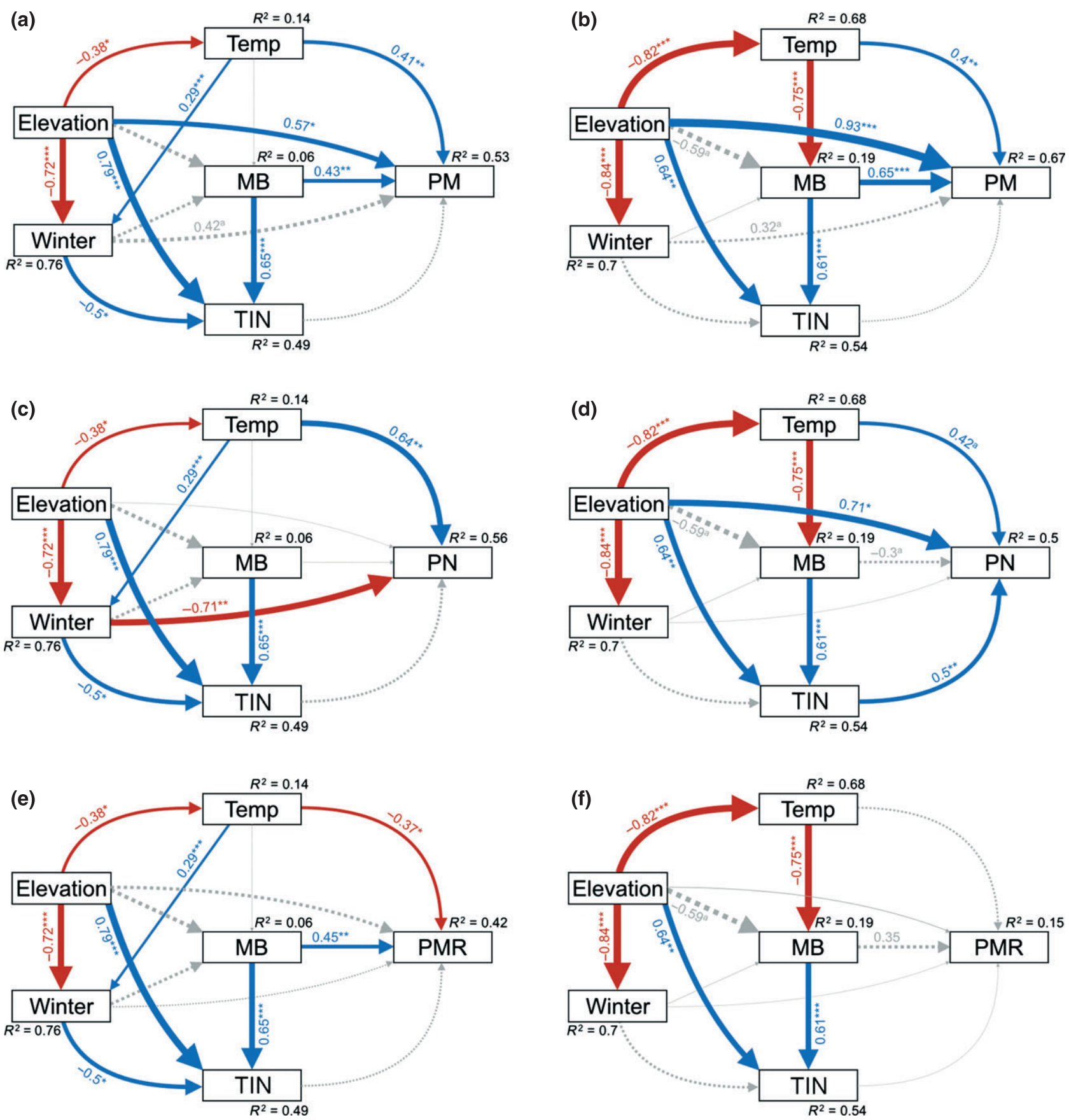

Fig. 4 Final structural equation models based on the different variables evaluated in this study: potential mineralization rate in spring (a) and summer (b), nitrification rate in spring (c), and summer (d), and microbial respiration rate in spring (e) and summer (f). Numbers adjacent to arrows are path coefficients and are indicative of the effect size of the relationship. Blue and red arrows indicate significant positive and negative relationships respectively. Dashed arrows indicate non-significant relationships. Width of arrows is proportional to the strength of path coefficients. $R^{2}$ appears above the response variable in the model and denotes the proportion of variance explained. Models satisfactorily fitted to our data, as suggested by the $\chi^{2}$ and RMSEA values $\left[\chi^{2}=0.4(P=0.534)\right.$, RMSEA $=0$ $P=0.554), \mathrm{df}=1$ in spring; and $\chi^{2}=3.6(P=0.164)$, RMSEA $=0.144(P=0.192), \mathrm{df}=2$ in summer $) . * * P<0.001,{ }^{* *} P<0.01,{ }^{*} P<0.05$, ${ }^{\text {a }} P<0.1$. Variable abbreviations are as in Table 1.

freezing (Stuanes et al., 2008; Brooks et al., 2011). The higher inorganic $\mathrm{N}$ content with increasing elevation at three of the four sampling dates supports this idea, but the lack of relationships between elevation and microbial biomass suggests that slower nitrification rates are more likely due to stresses or changes in 

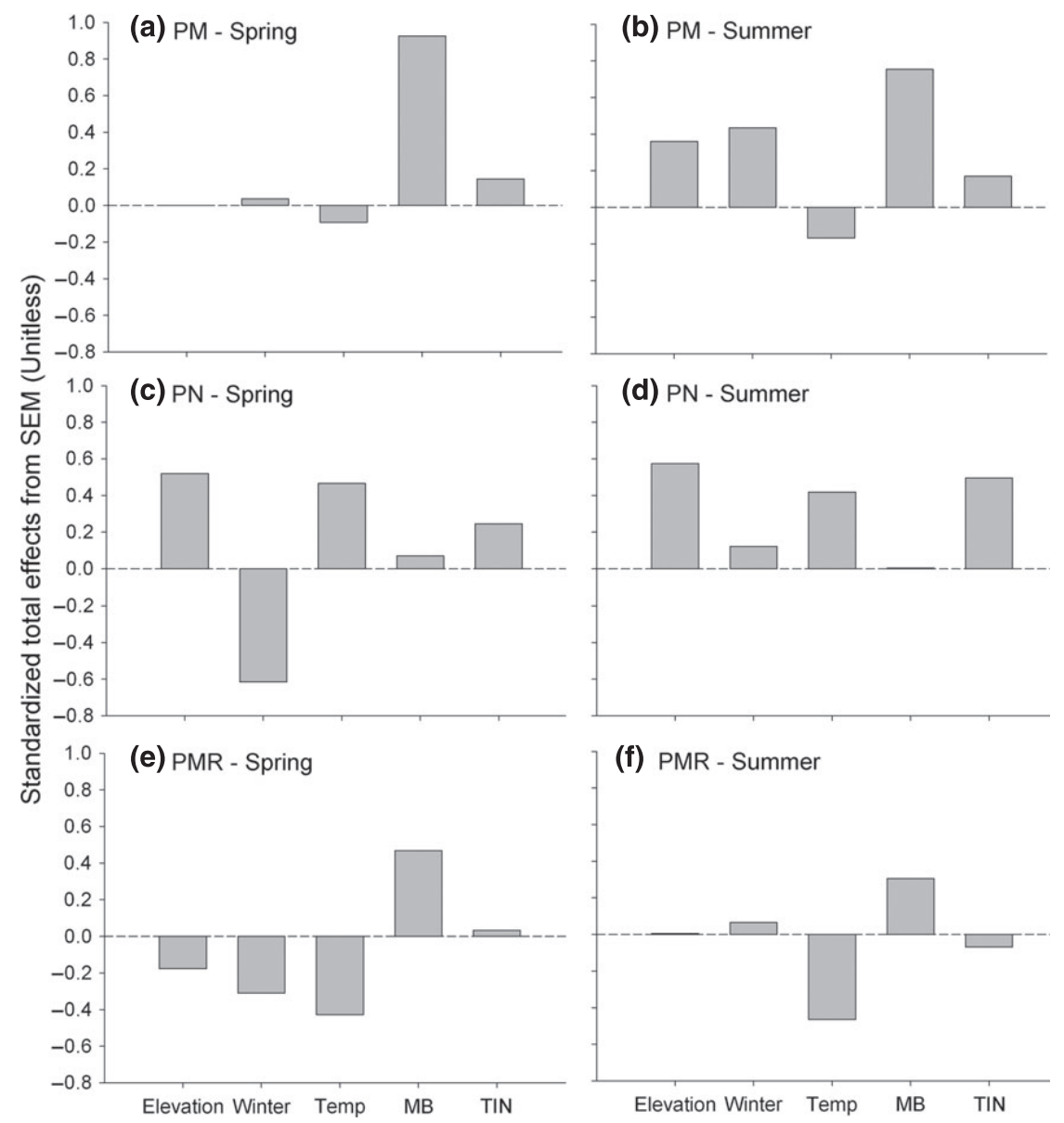

(d) PN - Summer
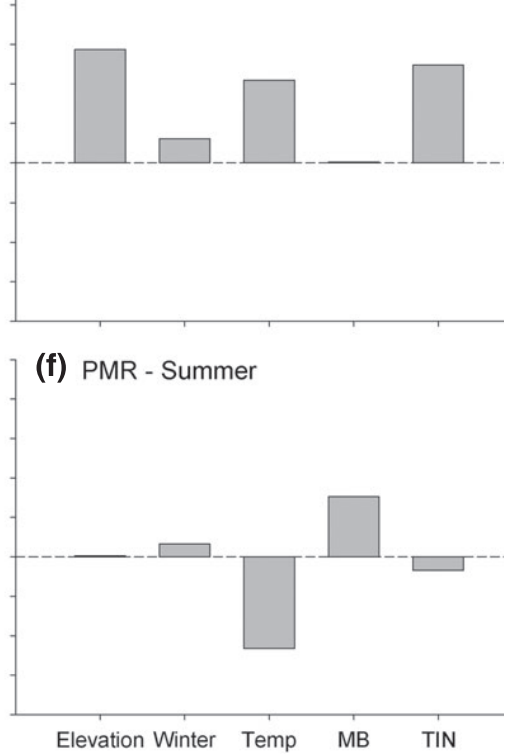

Fig. 5 Standardized total effects (direct plus indirect effects) derived from structural equation modeling of elevation, winter conditions, temperature, microbial biomass, and total inorganic nitrogen (TIN) on potential mineralization rates in spring (a) and summer (b), nitrification rates in spring (c) and summer (d), and microbial respiration rates in spring (e) and summer (f). Variable abbreviations are as in Table 1.

microbial populations rather than to a net reduction in biomass. Moreover, the importance of winter conditions in explaining potential nitrate production rates was more evident in spring than in summer, which confirms our hypothesis that winter climate effects are likely to be more important at the beginning rather than at the end of the growing season. It is likely that microbial populations stressed and/or killed due to winter freezing recover as the growing season progresses (Groffman et al., 1993; Brooks et al., 1998).

Microbial respiration rates tended to be slightly but not significantly higher in low elevation plots, which could be a product of moderate increases in C supply from plants, which [by potentially increasing the uptake of inorganic N; but see Campbell et al. (2014)] could be contributing to the decreases in $\mathrm{N}$ availability discussed above (Hart et al., 1994). However, the absence of statistically significant results suggests that $\mathrm{N}$ transformation rates were clearly more sensitive to changes in winter conditions than microbial respiration rates, which in our study were more strongly controlled by the amount of microbial biomass. This asymmetrical response of $C$ and $\mathrm{N}$ cycles to changes in climate has been observed previously, and indicates that some components of the microbial biomass may be more susceptible to global change drivers than others (Durán et al., 2013). We only addressed a limited number of microbial processes, and therefore generalization from our results should be done with caution. Although we have only 2 years of data, these findings suggest that specific changes within the microbial community may be a key regulator of how interactions between $\mathrm{C}$ and $\mathrm{N}$ cycles will respond to climate change, and highlights the need for more comprehensive analysis of how changes in soil microbial communities involved in $\mathrm{C}$ and $\mathrm{N}$ cycling drive mechanistic responses of ecosystem processes to climate change (Gubry-Rangin et al., 2011).

In some ways, our results contradict past manipulative studies carried out at the HBEF that found that snow removal treatments that increased soil freezing lead to 
increases in inorganic $\mathrm{N}$ content and fluxes following winter (e.g., Fitzhugh et al., 2001, 2003; Tierney et al., 2001; Cleavitt et al., 2008). However, the most responsive variables in those studies were soil solution chemistry and root mortality, which we did not specifically address here. Rather, we conducted detailed analysis of microbial biomass and potential activity, which were surprisingly unresponsive to snow pack removal in the previous manipulative studies. Here we show, for the first time, strong and consistent links between winter climate conditions and potential microbial nitrifying activity during the growing season, particularly in the spring, a critical period for $\mathrm{N}$ losses in forested ecosystems. These links were clear even when the 2 years of sampling had very different winter conditions. Thus, our results suggest that changes in winter soil temperature variability may be as or more important than changes in soil freezing, which was the focus of previous manipulation studies. Results here also show that winter climate effects on $\mathrm{N}$-related processes could be different than those on C-related processes. Overall, the results presented here suggest that winter climate change is likely to be a key driver of forest ecosystem $\mathrm{N}$ dynamics over the next 50-100 years with important implications for ecosystem productivity and water quality.

\section{Acknowledgements}

We thank Don Buso, Tammy Wooster, Lisa Martel, Kate Shepard, Erica Morgan, Robin Schmidt, and James Burtis for excellent field, laboratory, and data analysis work. We also thank Alexandra Rodríguez and Manuel Delgado-Baquerizo for editing the manuscript and assisting with statistical analysis, respectively. This research was supported by the US National Science Foundation (Grants DEB 0949664 - Ecosystem Studies and DEB 1114804 - Long-Term Ecological Research). J. D. was supported by a Fulbright fellowship of the Spanish Ministry of Education and by a FCT Research Fellowship of the Portuguese Ministry of Education and Science (SFRH/BDP/87966/2012).

\section{References}

Beier C, Emmett BA, Peñuelas J et al. (2008) Carbon and nitrogen cycles in European ecosystems respond differently to global warming. The Science of the total environment, 407, 692-697.

Bernal S, Hedin LO, Likens GE, Gerber S, Buso DC (2012) Complex response of the forest nitrogen cycle to climate change. Proceedings of the National Academy of Sciences, 109, 3406-3411.

Bernhardt ES, Likens GE, Hall RO et al. (2005) Can't see the forest for the stream? Instream processing and terrestrial nitrogen exports. BioScience, 55, 219-230.

Blankinship JC, Hart SC (2012) Consequences of manipulated snow cover on soil gaseous emission and $\mathrm{N}$ retention in the growing season: a meta-analysis. Ecosphere, 3 , art1.

Bohlen PJ, Groffman PM, Driscoll CT, Fahey TJ, Siccama TG (2001) Plant-soil-microbial interactions in a Northern hardwood forest. Ecology, 82, 965-978.

Brooks PD, Williams MW, Schmidt SK (1998) Inorganic nitrogen and microbial biomass dynamics before and during spring snowmelt. Biogeochemistry, 43, 1-15.

Brooks PD, Grogan P, Templer PH, Groffman P, Öquist MG, Schimel J (2011) Carbon and nitrogen cycling in snow-covered environments. Geography Compass, 5, 682-699.
Burnham KP, Anderson DR (2002) Model Selection and Multi-Model Inference: A Practical Information-Theoretic Approach (2nd edn). Springer, New York. 488 pp.

Campbell JL, Mitchell MJ, Groffman PM, Christenson LM, Hardy JP (2005) Winter in northeastern North America: a critical period for ecological processes. Frontiers in Ecology and the Environment, 3, 314-322.

Campbell JL, Driscoll CT, Eagar C et al. (2007) Long-term trends from ecosystem research at the Hubbard Brook Experimental Forest. Gen. Tech. Rep. NRS-17. US Department of Agriculture, Forest Service, Northern Research Station, Newtown Square, PA, 41

Campbell JL, Ollinger SV, Flerchinger GN, Wicklein H, Hayhoe K, Bailey AS (2010) Past and projected future changes in snowpack and soil frost at the Hubbard Brook Experimental Forest, New Hampshire, USA. Hydrological Processes, 24, 2465-2480.

Campbell JL, Driscoll CT, Pourmokhtarian A, Hayhoe K (2011) Streamflow responses to past and projected future changes in climate at the Hubbard Brook Experimental Forest, New Hampshire, United States. Water Resources Research, 47, W02514.

Campbell JL, Socci AM, Templer PH (2014) Increased nitrogen leaching following soil freezing is due to decreased root uptake in a northern hardwood forest. Global Change Biology, doi: 10.1111/gcb.12532.

Cleavitt NL, Fahey TJ, Groffman PM, Hardy JP, Henry KS, Driscoll CT (2008) Effects of soil freezing on fine roots in a northern hardwood forest. Canadian Journal of Forest Research, 38, 82-91.

Comerford DP, Schaberg PG, Templer PH, Socci AM, Campbell JL, Wallin KF (2013) Influence of experimental snow removal on root and canopy physiology of sugar maple trees in a northern hardwood forest. Oecologia, 171, 261-269.

Delgado-Baquerizo M, Maestre FT, Gallardo A et al. (2013) Decoupling of soil nutrient cycles as a function of aridity in global drylands. Nature, 502, 672-676.

Durán J, Rodríguez A, Morse JL, Groffman PM (2013) Winter climate change effects on soil $\mathrm{C}$ and $\mathrm{N}$ cycles in urban grasslands. Global change biology, 19, 2826-2837.

Fekedulegn DB, Andrew ME, Burchfiel CM, Violanti JM, Hartley TA, Charles LE, Miller DB (2007) Area under the curve and other summary indicators of repeated waking cortisol measurements. Psychosomatic medicine, 69, 651-659.

Fitzhugh R, Driscoll C, Groffman P, Tierney G, Fahey T, Hardy J (2001) Effects of soil freezing disturbance on soil solution nitrogen, phosphorus, and carbon chemistry in a northern hardwood ecosystem. Biogeochemistry, 56, 215-238.

Fitzhugh RD, Driscoll CT, Groffman PM, Tierney GL, Fahey TJ, Hardy JP (2003) Soil freezing and the acid-base chemistry of soil solutions in a northern hardwood forest. Soil Science Society of America Journal, 67, 1897-1908.

Gilliam FS, Cook A, Lyter S (2010) Effects of experimental freezing on soil nitrogen dynamics in soils from a net nitrification gradient in a nitrogen-saturated hardwood forest ecosystem. Canadian Journal of Forest Research, 40, 436-444.

Goodale CL, Aber JD, Vitousek PM (2003) An unexpected nitrate decline in new Hampshire streams. Ecosystems, 6, 0075-0086.

Grace JB (2006) Structural Equation Modeling and Natural Systems. Cambridge University Press, Cambridge. 378 pp.

Groffman PM, Zak DR, Christensen S, Mosier A, Tiedje JM (1993) Early spring nitrogen dynamics in a temperate forest landscape. Ecology, 74, 1579.

Groffman P, Driscoll C, Fahey T, Hardy J, Fitzhugh R, Tierney G (2001) Colder soils in a warmer world: a snow manipulation study in a northern hardwood forest ecosystem. Biogeochemistry, 56, 135-150.

Groffman P, Hardy J, Fisk M, Fahey T, Driscoll C (2009) Climate variation and soil carbon and nitrogen cycling processes in a northern hardwood forest. Ecosystems, 12, 927-943.

Groffman PM, Hardy JP, Fashu-Kanu S, Driscoll CT, Cleavitt NL, Fahey TJ, Fisk MC (2010) Snow depth, soil freezing and nitrogen cycling in a northern hardwood forest landscape. Biogeochemistry, 102, 223-238.

Groffman P, Hardy J, Fashu-Kanu S, Driscoll C, Cleavitt N, Fahey T, Fisk M (2011) Snow depth, soil freezing and nitrogen cycling in a northern hardwood forest landscape. Biogeochemistry, 102, 223-238.

Gubry-Rangin C, Hai B, Quince C et al. (2011) Niche specialization of terrestrial archaeal ammonia oxidizers. Proceedings of the National Academy of Sciences, 108, 21206-21211.

Hamburg SP, Vadeboncoeur MA, Richardson AD, Bailey AS (2013) Climate change at the ecosystem scale: a 50-year record in New Hampshire. Climatic Change, 116, $457-477$.

Hardy J, Groffman P, Fitzhugh R et al. (2001) Snow depth manipulation and its influence on soil frost and water dynamics in a northern hardwood forest. Biogeochemistry, 56, 151-174.

Hart SC, Nason GE, Myrold DD, Perry DA (1994) Dynamics of gross nitrogen transformations in an old-growth forest: the carbon connection. Ecology, 75, 880-891.

Hayhoe K, Wake C, Huntington T et al. (2007) Past and future changes in climate and hydrological indicators in the US Northeast. Climate Dynamics, 28, 381-407. 
Hayhoe K, Wake C, Anderson B et al. (2008) Regional climate change projections for the Northeast USA. Mitigation and Adaptation Strategies for Global Change, 13, 425-436.

Henry HAL (2008) Climate change and soil freezing dynamics: historical trends and projected changes. Climatic Change, $87,421-434$

Intergovernmental Panel on Climate Change (2013) Climate Change 2013 - The Physical Science Basis: Working Group I Contribution to the Fifth Assessment Report of the Intergovernmental Panel on Climate Change. Cambridge University Press, Cambridge. $1552 \mathrm{pp}$.

Jenkinson DS, Powlson DS (1976) The effects of biocidal treatments on metabolism in soil -V: a method for measuring soil biomass. Soil Biology and Biochemistry, 8, 209-213.

Kreyling J, Peršoh D, Werner S, Benzenberg M, Wöllecke J (2012) Short-term impacts of soil freeze-thaw cycles on roots and root-associated fungi of Holcus lanatus and Calluna vulgaris. Plant and Soil, 353, 19-31.

LeBauer DS, Treseder KK (2008) Nitrogen limitation of net primary productivity in terrestrial ecosystems is globaly distributed. Ecology, 89, 371-379.

Luo Y, Melillo J, Niu S et al. (2011) Coordinated approaches to quantify long-term ecosystem dynamics in response to global change. Global Change Biology, 17, 843-854.

McArdle BH, Gaston KJ (1995) The temporal variability of densities: back to basics. Oikos, 74, 165-171.

McInnes K, Weaver R (1994) Soil water potential. In: Methods of Soil Analysis, part 2Microbiological and Biochemical Properties (ed. Weaver R), pp. 53-58. Soil Science Society of America, Madison, WI

Melillo JM, Butler S, Johnson J et al. (2011) Soil warming, carbon-nitrogen interactions, and forest carbon budgets. Proceedings of the National Academy of Sciences, 108, 9508-9512. 201018189.

Monson RK, Lipson DL, Burns SP, Turnipseed AA, Delany AC, Williams MW, Schmidt SK (2006) Winter forest soil respiration controlled by climate and microbial community composition. Nature, $439,711-714$.

Morse JL, Ardón M, Bernhardt ES (2012) Greenhouse gas fluxes in southeastern US coastal plain wetlands under contrasting land uses. Ecological Applications, 22, 264-280.

Nelson D, Summers L (1996) Total carbon, organic carbon and organic matter. In: Methods of Soil Analysis. Part 3. Chemical Methods (ed. Sparks DL), pp. 539-579. American Society of Agronomy-Soil Science Society of America, Madison.

Pendall E, Rustad L, Schimel J (2008) Towards a predictive understanding of belowground process responses to climate change: have we moved any closer? Functional Ecology, 22, 937-940.

Rasmussen C, Southard RJ, Horwath WR (2006) Mineral control of organic carbon mineralization in a range of temperate conifer forest soils. Global Change Biology, 12, 834-847.

Schimel JP, Clein JS (1996) Microbial response to freeze-thaw cycles in tundra and taiga soils. Soil Biology and Biochemistry, 28, 1061-1066.

Schwarz PA, Fahey TJ, McCulloch CE (2003) Factors controlling spatial variation of tree species abundance in a forested landscape. Ecology, 84, 1862-1878.

Socci AM (2011) Impact of Winter Climate Change on Nutrient and Water Uptake in a Northern Forest Ecosystem. Boston University, Boston.

Sternberg M, Holzapfel C, Tielborger K et al. (2011) The use and misuse of climatic gradients for evaluating climate impact on dryland ecosystems - an example for the solution of conceptual problems. In: Climate Change - Geophysical Foundations and Ecological Effects (ed. Blanco JA), pp. 361-374. InTech, Rijeka.

Stuanes AO, de Wit HA, Hole LR, Kaste O, Mulder J, Riise G, Wright RF (2008) Effect of climate change on flux of $\mathrm{N}$ and $\mathrm{C}$ : air-land-freshwater-marine links: synthesis. Ambio, 37, 2-8.
Tierney GL, Fahey TJ, Groffman PM, Hardy JP, Fitzhugh RD, Driscoll CT (2001) Soil freezing alters fine root dynamics in a northern hardwood forest. Biogeochemistry, 56, 175-190.

Tilman D, Downing JA (1994) Biodiversity and stability in grasslands. Nature, 367, 363-365.

Walther G-R, Post E, Convey P et al. (2002) Ecological responses to recent climate change. Nature, 416, 389-395.

Yanai RD, Vadeboncoeur MA, Hamburg SP et al. (2013) From missing source to missing sink: long-term changes in the nitrogen budget of a northern hardwood forest. Environmental Science \& Technology, 47, 11440-11448.

Zion MS, Pradhanang SM, Pierson DC, Anandhi A, Lounsbury DG, Matonse AH, Schneiderman EM (2011) Investigation and modeling of winter streamflow timing and magnitude under changing climate conditions for the Catskill Mountain region, New York, USA. Hydrological Processes, 25, 3289-3301.

\section{Supporting Information}

Additional Supporting Information may be found in the online version of this article:

Figure S1. Significant univariate linear regressions [ordinary least-squares (OLS)] between elevation (as the only predictor) and soil temperature, volumetric water content, organic matter, microbial biomass, total inorganic nitrogen, and potential mineralization, nitrification and microbial respiration rates, in spring (upper row) and summer (lower row) of 2011. Variable abbreviations are as in Table 1.

Figure S2. Significant univariate linear regressions [ordinary least-squares (OLS)] between elevation (as the only predictor) and soil temperature, volumetric water content, soil organic matter, and microbial respiration rates, in spring (upper row) and summer (lower row) of 2012. Variable abbreviations are as in Table 1.

Figure S3. Univariate linear regression [ordinary leastsquares (OLS)] between 'snow' (as the only predictor) and 'Swtv'. in the winters of 2010-2011 and 2011-2012. Variable abbreviations are as in Table 1.

Figure S4. Daily min/max (area) and mean (line) soil temperature in the OiOe horizon in high and low elevation plots, from December 1st to May 1st, in the Winters 2010 2011 and 2011-2012.

Table S1. Univariate linear regressions [ordinary leastsquares (OLS)] between potential mineralization rates (PM), potential nitrification rates $(\mathrm{PN})$, and microbial respiration (PMR), and their expected predictors in spring and summer of 2011 and 2012. Abbreviations are as in Table 1. 